Jerzy Adamczyk ${ }^{1}$

Wyższe Seminarium Duchowne w Radomiu, Polska

\title{
Środki katechizacji w ujęciu prawa kanonicznego
}

\section{Wstęp}

Papież Jan Paweł II w adhortacji apostolskiej Catechesi tradendae pisze: „katecheza potrzebuje stałej odnowy przez pewne pogłębienie samego jej pojęcia i jej podstaw pedagogicznych, przez poszukiwanie stosownego dla niej języka, przez wykorzystanie nowych środków do skutecznego przekazu własnego orędzia"”2. Przypomina również, że

od czasów gdy Apostołowie nauczali ustnie, a w Kościołach odczytywano listy, aż do czasów dzisiejszych wyposażonych we wszelkiego rodzaju pomoce, katecheza pobudzana przez Pasterzy i przy współudziale wspólnot zawsze szukała dróg i środków najbardziej odpowiednich dla wypełnienia swej misji. Wysiłek ten powinien być oczywiście podtrzymywany3 .

Konieczność zastosowania w nauczaniu katechetycznym różnego rodzaju pomocy zdaje się nie podlegać kwestii. Wykorzystanie środków nauczania jest bowiem jedną z zasad warunkujących optymalizację procesu kształcenia przez wielostronną aktywizację ucznia. Środki dydaktyczne umożliwiają łatwiejsze osiągnięcie celów katechezy, aby wierni mogli głębiej poznać naukę katolicką i lepiej według niej układać życie ${ }^{4}$.

\footnotetext{
${ }^{1}$ Ksiądz Jerzy Adamczyk - doktor habilitowany prawa kanonicznego; wykładowca WSD w Radomiu; e-mail: ksjerzyad@wp.pl. ORCID: 0000-0003-1415-7378.

${ }^{2}$ Ioannes Paulus P.P. II, Adhortatio Apostolica, Catechesi tradendae (16 octobris 1979) 17, „Acta Apostolicae Sedis” 71 (1979), 1277-1340, tekst polski: Katecheza po Soborze Watykańskim II w świetle dokumentów Kościoła, red. W. Kubik, cz. II, Warszawa 1985, s. 146-217 [odtąd: CT].

${ }^{3}$ CT 46.

${ }^{4}$ Por. kan. 779; por. J. Szpet, Dydaktyka katechezy, Poznań 1999, s. 238.
} 
Nic więc dziwnego, że także prawodawcy kościelni przypisują ważne znaczenie różnego rodzaju pomocom katechetycznym, które wydają się bardziej skuteczne do tego, ,ażeby wiara wiernych przez przyjmowanie nauki i doświadczenie życia chrześcijańskiego stawała się żywa, wyraźna i czynna"s. Katecheza ma więc ściśle łączyć ortodoksję i ortopraksję ${ }^{6}$. Niniejszy artykuł podejmuje kwestię środków katechizacji w aspekcie kanonicznym.

\section{Konieczność narzędzi katechetycznych}

$\mathrm{Na}$ nieodzowność posługiwania się $\mathrm{w}$ procesie katechetycznym środkami nauczania i pomocami dydaktycznymi wskazuje dyspozycja kan. 779, gdzie prawodawca wymaga, aby nauczanie katechetyczne było prowadzone z zastosowaniem wszelkich środków, pomocy dydaktycznych oraz środków społecznego przekazu. Jest to w stosunku do Kodeksu z 1917 r. nowość, gdyż nie poruszano tam w ogóle tej kwestii ${ }^{7}$.

Na konieczność stosowania środków i pomocy katechetycznych wskazywała już dyspozycja kan. 31 schematu KPK z 1977 r. Czytamy tam, że w formacji katechetycznej „należy zastosować wszystkie możliwe środki, pomoce dydaktyczne oraz środki społecznego przekazu”, jak również „Konferencje Episkopatu $[\ldots]$ winny czuwać nad tym [...] by przygotowano i rozpowszechniono Dyrekto-

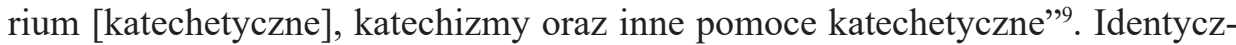
nie jak obowiązujący Kodeks o środkach katechizacji mówiły schematy KPK z $1980^{10}$ i z 1982 r. ${ }^{11}$

O potrzebie wykorzystywania różnych pomocy katechetycznych traktuje również kan. $775 \S 1$, gdzie prawodawca zobowiązuje biskupa diecezjalnego

\footnotetext{
${ }^{5}$ Kan. 773; zob. J. Passicos, Le statut des instruments de cathéchèse dans le Code, „L'Année canonique" 31 (1988), s. 147-156, tu: s. 147, 149.

${ }^{6}$ Por. J. Passicos, Le statut..., s. 150.

7 Zob. kan. 1329-1336 KPK z 1917 r.

${ }^{8}$ Pontificia Commissio Codici Iuris Canonici Recognoscendo, Schema canonum libri III De ecclesiae munere docendi, can. 31, Città del Vaticano 1977, tekst polski: „Posoborowe Prawodawstwo Kościelne", t. 11 z. 1, nr. 21077-21259, s. 286-328.

${ }^{9}$ Can. $26 \S 1$.

10 „Institutio catechetica tradatur omnibus adhibitis auxiliis, subsidiis didacticis et communicationis socialis instrumentis". Schema Codicis Iuris Canonici, Libreria Editrice Vaticana 1980, can. 734.

11 „Institutio catechetica tradatur omnibus adhibitis auxiliis, subsidiis didacticis et communicationis socialis instrumentis". Codex Iuris Canonici. Schema novissimum iuxta placita Patrum Commissionis emendatum atque Summo Pontifici praesentatum, Typis Polyglottis Vaticanis 1982, can. 779.
} 
do troski o dostarczenie odpowiednich pomocy katechetycznych ${ }^{12}$. Identyczne postanowienia w sprawie konieczności przygotowania instrumentów katechizacji zawierały Schema canonum libri III De ecclesiae munere docendi z 1980 r. ${ }^{13}$ i Schema novissimum z 1982 r. ${ }^{14}$

Opierając się na kan. $775 \S 1$ obowiązującego Kodeksu, Dyrektorium Ogólne o Katechizacji wskazuje na nieodzowność środków katechizacji:

troska o katechizację powinna prowadzić biskupa do podjęcia „najwyższego kierownictwa katechizacji” w Kościele partykularnym, co zakłada między innymi: zapewnienie w swoim Kościele faktycznego pierwszeństwa czynnej i skutecznej katechezie, która obejmie „ludzi, pomoce i urządzenia, a także konieczne fundusze" $"$.

Dyrektorium o pasterskiej posłudze biskupów przypomina, że jednym z zadań powierzonych Konferencji Episkopatu jest troska o „pomoce do katechizacji diecezjalnej”16. Według tego dokumentu „biskup powinien także zatroszczyć się o to, by wyposażyć diecezję w odpowiednie narzędzia służące katechizacji: [...] następnie [dostarczyć] odpowiednie pomoce do prowadzenia katechizacji" ${ }^{17}$. Przywołane dyrektorium, nawiązując do kan. 775 § 1, podkreśla, że „na biskupach spoczywa zadanie podania $w$ tym względzie bardziej dokładnych norm i zastosowania ich przez dyrektoria katechetyczne, katechizmy dostosowane do różnego wieku i warunków kulturowych oraz inne środki uznane za bardziej odpowiednie" 18 .

Pośrednio o konieczności wykorzystania w nauczaniu katechetycznym odpowiednich pomocy mówi także dyrektorium Ecclesiae imago. Redaktorzy tego dokumentu przypominają: „,mając na uwadze owocniejsze prowadzenie katechizacji Biskup uważnie analizuje i wprowadza w życie zasady, wskazówki i normy wydane w tej materii przez Stolicę Apostolską". W tym miejscu autorzy odwołują się do Ogólnej Instrukcji Katechetycznej, w której poleca się wykorzystanie wspomnianych pomocy ${ }^{19}$.

\footnotetext{
12 Por. can. $386 \S 1$.

13 Can. $730 \S 1$.

14 Can. $775 \S 1$.

15 Kongregacja ds. Duchowieństwa, Dyrektorium Ogólne o Katechizacji, Poznań 1998 [odtąd: DOK]; por. CT 63.

${ }^{16}$ Kongregacja do spraw Biskupów, Dyrektorium o pasterskiej postudze biskupów „Apostolorum Successores”, Kielce 2005 [odtąd: AS].

17 Tamże 128.

18 Tamże 118. Przypis nr 117 powołuje się na kan. 775 § 1-3.

19 Sacra Congregatio pro Episcopis, Directorium Ecclesiae imago de pastorali ministerio Episcoporum (22 februarii 1973) 64, w: Enchiridion Vaticanum, t. 4, Bologna 1997 nr. 1945-2328, tekst polski: E. Sztafrowski, „Posoborowe Prawodawstwo Kościelne”, t. 6, z. 1, nr. 10370-11035.
} 
Prawodawca poleca, aby stosować wszelkie środki, pomoce dydaktyczne oraz mass media, które wydają się skuteczniejsze do tego, by wierni, w sposób dostosowany do ich charakteru, możliwości, wieku oraz warunków życia, mogli głębiej poznać naukę katolicką i lepiej według niej układać życie ${ }^{20}$. Nie jest więc obojętne dla osiągania celów katechezy wybranie raczej tej, a nie innej pomocy dydaktycznej albo środka komunikacji. Aby przekazywać katechezę należy wykorzystać wszystkie środki, które są dostępne, i które wydają się skuteczniejsze. Cel, który winien przyświecać w wyborze pomocy, jest ten, aby były one, albo przynajmniej wydawały się, najskuteczniejsze, aby „wierni mogli głębiej poznać naukę katolicką i lepiej według niej układać życie"21.

Skuteczność narzędzi katechetycznych winna być oceniana na podstawie ich większej zgodności z charakterem wiernych, według różnych ich kategorii, z ich zdolnością do przyjęcia nauki, biorąc pod uwagę także stopień ich kultury, wiek i warunki życia. Mając to wszystko na uwadze, trzeba dobierać pomoce i środki komunikacji, dawne i nowoczesne, uwzględniając także uzdolnienia katechetów w tej kwestii ${ }^{22}$.

Trzeba dodać, że w kan. 779 oprócz proklamowania obowiązku, który mają odpowiedzialni za katechezę - używać wszystkich typów narzędzi katechetycznych — postanawia się także, że muszą być one dostosowane do potrzeb, a w związku z tym do praw wiernych w tym względzie. W przystosowywaniu środków katechetycznych do oczekiwań katechizowanych, należy brać pod uwagę potrzeby duszpasterskie, rozmaitość narzędzi dydaktycznych i konieczność pobudzania przez pasterzy różnych inicjatyw katechetycznych, jakie pojawią się wśród wiernych ${ }^{23}$.

Prawodawca kodeksowy nie tylko przypomina o konieczności używania pomocy katechetycznych oraz ich dostosowania do różnych uwarunkowań odbior-

Występujący przy przywołanym fragmencie przypis nr 12 odwołuje się do Directorium Catechisticum Generale. Dyrektorium to traktuje o pomocach dydaktycznych szczególnie w nr. 116-124.

${ }^{20}$ Por. kan. 779.

${ }^{21}$ Por. A. Urru, La funzione di insegnare della Chiesa, Roma 1988, s. 70-71; por. H. Mussinghoff, H. Kahler, Verkündigungsamt: Dienst am Wort Gottes, w: Kommentar zum Codex Iuris Canonici, Bd. 3, hrsg. v. K. Lüdicke, Essen 1988-2001, kan. 779.

${ }^{22}$ Por. kan. 779. „Kapłan powinien ponadto umieć przekazywać nauczanie katechetyczne, wykorzystując materiały uzupełniające, pomoce dydaktyczne i środki przekazu, które mogą przyczynić się do tego, by wierni, w sposób dostosowany do ich charakteru, zdolności, wieku i praktycznych warunków życia, byli w stanie w pełni wniknąć w doktrynę chrześcijańską i stosować ją w sposób jak najbardziej odpowiedni w praktyce". Kongregacja ds. Duchowieństwa, Dyrektorium o postudze i życiu kapłanów, Città del Vaticano 1994; A. Urru, La funzione..., s. 71; J. Fuentes, Comentario al can. 779, w: Comentario exegético al Código de Derecho Canónico, red. A. Marzoa, J. Miras, R. Rodríguez-Ocaña, v. 3, p. I, Pamplona 20023 , s. 155-156, tu: s. 155; por. J. Passicos, Le statut..., s. 149.

${ }^{23}$ Por. J. Fuentes, Comentario..., s. 155. 
ców katechezy, ale także wskazuje cel wykorzystania wspomnianych pomocy. Kan. 779 precyzuje cel narzędzi katechetycznych: „by wierni, w sposób dostosowany do ich charakteru, możliwości, wieku oraz warunków życia, mogli głębiej poznać naukę katolicką i lepiej według niej układać życie"24. Łatwo dostrzec, że korzystanie ze środków katechizacji odpowiada ogólnemu celowi nauczania katechetycznego. Uwyraźnia go kan. 773, mówiąc, iż celem katechizacji ludu chrześcijańskiego jest ,ażeby wiara wiernych przez przyjmowanie nauki i doświadczenie życia chrześcijańskiego stawała się żywa, wyraźna i czynna”, czyli aby wierni zostali uzdolnieni do głębszego zrozumienia doktryny katolickiej i wprowadzenia jej w odpowiedni sposób w życie ${ }^{25}$. O wymienionym celu katechezy mówił Jan Paweł II w adhortacji Catechesi tradendae: ,specyficznym jednak celem katechezy, do którego winna ona zmierzać, jest rozwinięcie z pomoca Bożą wiary dotąd początkowej, doprowadzenie jej do pełni i codzienne zasilanie życia chrześcijańskiego wiernych każdego wieku”, tak że chrześcijanin uczy się coraz lepiej „myśleć jak Chrystus, oceniać jak Chrystus, postępować zgodnie z Jego przykazaniami i ufać, tak jak On nas do tego wzywa"26.

\section{Narzędzia służące ukierunkowaniu i programowaniu całej działalności katechetycznej w Kościele partykularnym}

Dyrektorium Ogólne o Katechizacji rozróżnia dwa rodzaje środków katechizacji. Pierwsze to narzędzia poświęcone ukierunkowaniu i programowaniu całej działalności katechetycznej. Są to: analiza sytuacji, program działania i dyrektorium katechetyczne ${ }^{27}$. Druga kategoria pomocy w nauczaniu katechetycznym to „narzędzia robocze o zastosowaniu bezpośrednim, które są wykorzystywane w katechizacji”28.

Gdy chodzi o pierwszy rodzaj pomocy, to mieści się on w zakresie następującej dyspozycji kan. 779, gdzie czytamy: „nauczanie katechetyczne winno być prowadzone z zastosowaniem wszelkich środków". Owe środki prawodawca odróżnia od przytoczonych w tym kanonie „pomocy dydaktycznych oraz środków społecznego przekazu”. Chodzi więc w tej frazie kan. 779 (,nauczanie katechetyczne winno być prowadzone z zastosowaniem wszelkich środków”) o wspo-

\footnotetext{
24 Por. P. Urso, Il ministero della parola divina: predicazione e catechesi (cann. 756-780), w: La funzione di insegnare della Chiesa, a cura di Gruppo Italiano Docenti di Diritto Canonico, Milano 1994, s. 25-49, tu: s. 48.

25 Por. tamże.

26 CT 20; por. P. Urso, Il ministero..., s. 48.

27 DOK 283.

28 Tamże.
} 
mniane narzędzia poświęcone ukierunkowaniu i programowaniu całej działalności katechetycznej.

Odnośnie do omawianego rodzaju pomocy służących ukierunkowaniu i programowaniu całej działalności katechetycznej schemat KPK z 1977 r. zawiera następujący passus:

Konferencje Episkopatu winny wydać dla własnego terytorium normy dotyczące katechizacji oraz czuwać nad tym by właściwie przygotowano i rozpowszechniono Dyrektorium [katechetyczne], [...] jak również zabiegać o popieranie i koordynowanie działalności katechetycznej ${ }^{29}$.

Pierwszym rodzajem pomocy służącym ukierunkowaniu i programowaniu całej działalności katechetycznej jest analiza sytuacji.

Organizując działalność katechetyczną, Kościół partykularny powinien mieć jako punkt wyjścia analizę sytuacji. „Przedmiot tego dociekania jest wieloraki. Obejmuje bowiem badania działalności duszpasterskiej i analizę sytuacji religijnej, jak również warunków socjologicznych, kulturalnych i ekonomicznych, chodzi zaś przy tym o ustalenie, w jakim zakresie te fakty życia wspólnego mogą mieć wpływ na proces ewangelizacji”. Chodzi o uświadomienie sobie stanu rzeczywistości, rozważanej w odniesieniu do katechezy i do jej potrzeb ${ }^{30}$.

\section{Omawiana analiza dokonuje się na kilku poziomach. Po pierwsze}

w analizie działania duszpasterskiego trzeba mieć jasną świadomość stanu katechezy: jak jest ona rzeczywiście usytuowana w procesie ewangelizacyjnym; jak wygląda równowaga i artykulacja między różnymi sektorami katechetycznymi [dzieci, dorastający, młodzież, dorośli...]; jak przebiega koordynowanie katechezy z chrześcijańskim wychowaniem $\mathrm{w}$ rodzinie, z wychowaniem szkolnym, ze szkolnym nauczaniem religii i z innymi formami wychowania wiary; jak przed-

\footnotetext{
${ }^{29}$ Can. $26 \S 1$.

${ }^{30}$ DOK 279; Kongregacja ds. Duchowieństwa, Ogólna Instrukcja Katechetyczna (11 kwietnia 1971), nr 100, „Wiadomości Archidiecezjalne Warszawskie” 63 (1973) 2, s. 37-112 [odtąd: DCG]. Odnośnie do celu analizy sytuacji, w której dokonuje się nauczanie katechetyczne w DCG 99 czytamy: ,jest rzeczą konieczną, by w zasięgu Konferencji zdobyć jasne rozeznanie sytuacji, w której wykonuje się posługę słowa. Ta analiza zmierza do tego, by ustalić, w jakim stopniu może osiągnąć swój cel działalność ewangelizacyjna Kościoła. Stąd należy uważnie badać, w jaki sposób była wykonywana posługa słowa oraz, jakie są — na ile to jest dostępne dla ludzkiego poznania owoce osiągane przez katechezę lub inne formy przekazywania chrześcijańskiego orędzia. Trzeba poddać ocenie poczynania Kościoła: jak zostały przyjęte, gdzie, przez jakie osoby, z jakim skutkiem itd.".
} 
stawia się jej jakość wewnętrzna; jak wyglądają nauczane treści i stosowana metodologia; jakie są cechy charakterystyczne katechetów i ich formacja ${ }^{31}$.

Kolejną płaszczyzną analizy sytuacji jest rozpatrywanie sytuacji religijnej.

Obejmuje ono przede wszystkim trzy poziomy ściśle między sobą powiązane: zmysł sacrum, to znaczy tych doświadczeń ludzkich, które przez swoją głębię dążą do otwarcia się na misterium; zmysł religijny, czyli konkretne sposoby rozumienia Boga i komunikacji z Nim przez określony naród; sytuacje wiary u różnych typów ludzi wierzących. A w związku z tymi poziomami sytuacja moralna, jaką się przeżywa, z wartościami, jakie się wyłaniają, oraz cieniami i najszerzej rozpowszechnionymi antywartościami ${ }^{32}$.

Wreszcie trzeba dokonać analizy społeczno-kulturowej, aby przygotować katechetów, katechumenów i katechizowanych do obecności chrześcijańskiej w świecie ${ }^{33}$. Trzeba dodać, że ,analiza sytuacji jest pierwszym narzędziem roboczym o charakterze informacyjnym, jakie służba katechetyczna podaje duszpasterzom i katechetom" 34 .

Gdy idzie o sposób przeprowadzania omawianej analizy sytuacji i potrzeb w dziedzinie katechizacji, to jest konieczne,

aby uniknąć dwóch niebezpieczeństw: nie uważać za pewne elementów i stwierdzeń jeszcze dokładnie nie zbadanych i nie potwierdzonych; nie domagać się przeprowadzenia badań z taką doskonałością naukową, która jest nieosiągalna. Trzeba również zauważyć, że badania techniczne, podjęte na sposób problemów lub konsultacji, niewiele pomogą, jeżeli nie rozważy się uprzednio różnych form działalności duszpasterskiej, jakie można będzie zastosować. Konferencje biskupie winny mieć koniecznie pełne spojrzenie na sytuację, co można uzyskać przez konsultację z biegłymi, dobrze się orientującymi w analizie zebranych dowodów oraz przez wyciągnięcie wniosków z już zapoczątkowanej działalności duszpasterskiej. W tej dziedzinie mogą się okazać bardzo pożyteczne studia monograficzne. W zakresie badania sytuacji ma świadczyć pomoc cała wspólnota chrześcijańska, by stała się świadoma problemów i została przygotowana do działania ${ }^{35}$.

\footnotetext{
31 DOK 279.

32 Tamże.

33 Por. tamże.

34 Tamże.

35 DCG 101.
} 
Co się tyczy skutków omawianego badania sytuacji, nie jest ono

celem samo dla siebie, lecz winno ujawniać lepsze sposoby działania i wskazać drogę dla ich podjęcia, przyczyniając się zarówno do spotęgowania działalności i poczynań, których skuteczność została już potwierdzona, jak i do poparcia nowych. Chodzi bowiem o przewidywanie i przygotowanie tego wszystkiego, co należy koniecznie podjąć w przyszłości. Analiza, o której tu mowa, winna również przekonać osoby zajmujące się posługą słowa, że sytuacje ludzkie są ambiwalentne w odniesieniu do działalności duszpasterskiej. Dlatego pracownicy Ewangelii mają się uczyć odkrywać możliwości, jakie otwierają się dla ich działalności duszpasterskiej w nowej i odmiennej sytuacji. Istnieje wszakże niebezpieczeństwo, aby poznanie trudności nie prowadziło do wniosku, że działalność duszpasterska jest niemożliwa. $Z$ drugiej jednak strony każdy winien być przekonany, iż zjawiska kulturowe nie są elementami bezwładnymi, niezmiennymi, jednoznacznymi, tak że łaska i działalność duszpasterska nie mogą mieć na nie wpływu. Zawsze bowiem możliwy jest proces przemiany, który otwiera drogę dla wiary ${ }^{36}$.

Drugim istotnym narzędziem sprzyjającym ukierunkowaniu i programowaniu całej działalności katechetycznej są programy lub plany działania. Ukazują one cele, środki realizacji katechezy i normy, jakie ją regulują, z pełnym uwzględnieniem warunków i potrzeb miejscowych, a zarazem w pełnej harmonii z celami i normami Kościoła powszechnego. Programy lub plany działania powinny mieć charakter praktyczny, ponieważ winny ukierunkowywać działanie katechetyczne na szczeblu diecezjalnym lub międzydiecezjalnym. Jako takie obejmują one zazwyczaj określony czas, na końcu którego odnawia się je przez nowe akcenty, nowe cele i nowe środki ${ }^{37}$.

Cele programów lub planów działania mogą mieć rozmaite stopnie i formy, w zależności od różnych miejsc i potrzeb. Wszystkie jednak muszą mieć na uwadze wzrost wiary i życia chrześcijańskiego, jak również doskonalenie relacji chrześcijanina (katechizowanego) z Bogiem i bliźnimi ${ }^{38}$.

Trzeba dodać, że „program działania jest bardzo użyteczny dla katechezy, ponieważ w określaniu niektórych wspólnych celów sugeruje ujednolicenie wysiłków i wspólną pracę. Dlatego jego pierwszym warunkiem powinien być realizm połączony z prostotą, zwięzłością i jasnością" 39 .

Wreszcie narzędziem poświęconym ukierunkowaniu i programowaniu całej działalności katechetycznej jest „dyrektorium katechetyczne” i jemu podobne.

36 Tamże 102.

37 Por. DOK 281; por. DCG 103.

38 Por. DCG 104.

39 DOK 281; por. DCG 103. 
W przeciwieństwie do omówionych — analizy sytuacji i planów działania, skoncentrowanych przede wszystkim na czynnościach operacyjnych — dyrektoria opracowywane przez różne episkopaty na poziomie narodowym są narzędziami o charakterze bardziej refleksyjnym i ukierunkowującym, które dostarczają kryteriów dla właściwej katechezy.

Są one różnie nazywane: dyrektoria katechetyczne, ukierunkowania katechetyczne, dokumenty bazowe, teksty podstawowe itd. Przeznaczone przede wszystkim dla odpowiedzialnych za katechezę i katechetów, wyjaśniają one pojęcie katechezy: jej naturę, cel, zadania, treści, adresatów, metodę. Te dyrektoria lub wskazania ogólne, ustalane przez konferencje episkopatu lub wydawane pod ich nadzorem, powinny realizować ten sam proces opracowywania i zatwierdzania, jaki jest przewidziany dla katechizmów. Oznacza to, że przed promulgacją powinny być przedstawione do zatwierdzenia Stolicy Apostolskiej ${ }^{40}$.

Kompetentna do aprobaty dyrektoriów katechetycznych jest Kongregacja ds. Duchowieństwa, która „udziela przepisanej prawem aprobaty Stolicy Apostolskiej wymaganej dla katechizmów oraz innych wydań dotyczących katechetycznej formacji, mając zgodę Kongregacji Nauki Wiary"41.

Te dyrektywy lub wskazania katechetyczne (dyrektoria katechetyczne, ukierunkowania katechetyczne, dokumenty bazowe, teksty podstawowe) są ważnym elementem dostarczającym poważnej inspiracji dla katechizacji Kościołów lokalnych, a ich opracowanie jest zalecane i potrzebne, ponieważ, między innymi, stanowią ważny punkt odniesienia dla formacji katechetów ${ }^{42}$.

Trzeba jednak pamiętać, że narzędziem służącym działalności katechetycznej całego Kościoła jest Dyrektorium ogólne o katechizacji z 15 sierpnia 1997 r. $(\mathrm{DOK})^{43}$. „Przedstawia ono fundamentalne zasady teologiczno-duszpasterskie, zaczerpnięte z Nauczycielskiego Urzędu Kościoła oraz w sposób szczególny

${ }^{40}$ DOK 282. „Celem instrukcji jest wspomaganie i koordynowanie działalności katechetycznej na terytorium jakiegoś regionu lub kraju, ewentualnie nawet kilku krajów należących do tej samej grupy społeczno-kulturalnej. Zanim instrukcje zostaną ogłoszone, trzeba wysłuchać zdania poszczególnych ordynariuszy miejsca. Podlegają też one zatwierdzeniu ze strony Stolicy Apostolskiej". DCG 117, por. 134.

${ }^{41}$ Ioannes Paulus P.P. II, Constitutio Apostolica Pastor Bonus, (28 iulii 1988), „Acta Apostolicae Sedis” 80 (1988), s. 841-912, art. 94. „Ogólna odpowiedzialność za działalność katechetyczną na terytoriach prawa powszechnego została powierzona Kongregacji dla Spraw Duchowieństwa. Bada i zatwierdza instrukcje katechetyczne, katechizmy i programy dotyczące przepowiadania Słowa Bożego, a przygotowane przez Konferencje Biskupie”. DCG 134; zob. J. Fuentes, Comentario..., s. 141

42 Por. DOK 282.

${ }^{43}$ Dyrektorium to wydała Kongregacja ds. Duchowieństwa, po uprzednim zatwierdzeniu przez papieża Jana Pawła II 15 sierpnia 1997 r. Por. Constitutio Apostolica Pastor Bonus, art. 94. Po- 
z dokumentów Powszechnego Soboru Watykańskiego II, ażeby za ich pomocą lepiej wypełnić zadanie działalności katechetycznej w Kościele"44. Gdy idzie o rodzaj i autorytet, jaki nadaje temu instrumentowi katechizacji władza kościelna, to należy powiedzieć, że „Dyrektorium ogólne o katechizacji, ze swej strony, posiada taką wartość, jakiej Stolica Święta udziela zazwyczaj tym narzędziom o charakterze ukierunkowującym, aprobując je i zatwierdzając. Jest to oficjalna pomoc do przekazywania orędzia ewangelicznego i całości działalności katechetycznej"45.

\section{Katechizmy i inne pisma służące katechizacji}

Drugim rodzajem środków katechizacji wyróżnionym przez Dyrektorium Ogólne o Katechizacji są „narzędzia robocze o zastosowaniu bezpośrednim, które są wykorzystywane w katechizacji”" ${ }^{` 6}$. Są to przede wszystkim katechizmy: uniwersalny i lokalne.

Kościół zawsze podawał sformułowania wiary, które w zwięzłej formie zawierały istotę tego, w co wierzy i czym żyje: teksty nowotestamentalne, symbole lub wyznania wiary, formuly liturgiczne, modlitwy eucharystyczne. $Z$ biegiem czasu pojawiła się potrzeba podania szerszego wyjaśnienia wiary, na sposób organicznej syntezy, za pośrednictwem katechizmów, opracowanych w Kościołach lokalnych. Dwukrotnie w historii (z okazji Soboru Trydenckiego i 11 listopada 1992 r.) uznano za uzasadnione podanie organicznego wykładu wiary za pośrednictwem katechizmu o charakterze uniwersalnym jako punktu odniesienia dla katechezy całego Kościoła ${ }^{47}$.

Podstawowym narzędziem katechetycznym dla całego Kościoła, będącym punktem odniesienia dla jego katechezy jest Katechizm Kościoła Katolickiego ${ }^{48}$. Winien być on uważany

za punkt odniesienia dla katechizmów lub kompendiów przygotowywanych w różnych krajach. [...] nie ma zastąpić katechizmów opracowanych w różnych

\footnotetext{
przednie dyrektorium o katechizacji, już wielokrotnie przywoływane wyżej, to Ogólna Instrukcja Katechetyczna z 11 kwietnia 1971 r. (DCG).

${ }^{44}$ DOK 120.

45 Tamże.

46 Tamże 283.

47 Por. tamże 119.

48 Katechizm Kościoła Katolickiego, Poznań 1994 [odtąd: KKK]; por. J. Fuentes, Comentario..., s. 142-143; „Prezbiter powinien przyjąć jako pierwszorzędny punkt odniesienia Katechizm Kościoła Katolickiego. Stanowi on rzeczywiście pewną i autentyczną normę nauczania Kościoła”. Kongregacja ds. Duchowieństwa, Dyrektorium o postudze... 47.
} 
miejscach, ale ma stać się zachętą i pomocą do opracowania nowych katechizmów lokalnych, przystosowanych do różnorakich środowisk i kultur, a jednocześnie dbających o zachowanie jedności wiary oraz o wierność nauce katolickiej ${ }^{49}$.

Katechizm Kościoła Katolickiego „ma na celu przedstawienie organicznego i syntetycznego wykładu istotnych i podstawowych treści wiary katolickiej, obejmujących zarówno wiarę, jak i moralność w świetle Soboru Watykańskiego II i całości Tradycji Kościoła" ${ }^{50}$.

Gdy chodzi o funkcję, jaką Katechizmowi Kościoła Katolickiego nadaje władza Kościoła w podejmowaniu i odnowie działalności katechetycznej w naszych czasach, to trzeba powiedzieć, że jest on

przede wszystkim katechizmem, to znaczy oficjalnym tekstem Urzędu Nauczycielskiego Kościoła, który autorytatywnie, w precyzyjnej formie, na sposób organicznej syntezy, gromadzi podstawowe wydarzenia i prawdy zbawcze, wyrażające wspólną wiarę Ludu Bożego oraz stanowiące niezbędny i podstawowy punkt odniesienia dla katechezy ${ }^{51}$.

\section{Z kolei}

będąc katechizmem, Katechizm Kościoła Katolickiego gromadzi to, co jest podstawowe i wspólne w życiu chrześcijańskim, starając się nie przedstawiać jako nauki wiary osobliwych wyjaśnień, które stanowią jedynie prywatne opinie, ewentualnie poglądy jakiejś szkoły teologicznej ${ }^{52}$.

Wreszcie jest on „katechizmem uniwersalnym, ofiarowanym całemu Kościołowi. Jest w nim zawarta aktualna synteza wiary, która obejmuje nauczanie Soboru Watykańskiego II oraz pytania religijne i moralne naszych czasów"53.

W kwestii katechizmów lokalnych Dyrektorium Ogólne o Katechizacji przypomina, że „wśród wszystkich narzędzi katechetycznych najważniejsze miejsce zajmują katechizmy. Ich znaczenie wynika z faktu, że orędzie, jakie przekazują, jest uznane za autentyczne i własne przez pasterzy Kościoła" ${ }^{54}$. Są to oficjalne narzędzia Kościoła w odniesieniu do działalności katechetycznej kościoła partykularnego ${ }^{55}$. Określenie „katechizmy lokalne” odnosi się do katechizmów opra-

49 DOK 121.

${ }^{50}$ Tamże.

${ }^{51}$ Tamże 124.

52 Tamże.

53 Tamże.

${ }^{54}$ Tamże 284.

55 Por. tamże 119. 
cowywanych przez Kościoły partykularne lub Konferencje Episkopatu ${ }^{56}$. Rozróżniamy katechizmy: narodowe, regionalne lub diecezjalne ${ }^{57}$.

Katechizmy te, będąc „w komunii eklezjalnej, służą jako pomoc określonej części Ludu Bożego" 58. Przystosowują one „wykład i metody katechetyczne, jakich wymagają zróżnicowania kultury, wieku, życia duchowego oraz sytuacji społecznych i eklezjalnych tych, do których kieruje się katecheza" ${ }^{59}$. Muszą one pozostawać w ścisłym związku z Katechizmem Kościoła Katolickiego, który jest dla nich punktem odniesienia. Bowiem „Katechizm Kościoła Katolickiego nie ma zastąpić katechizmów opracowanych w różnych miejscach, ale ma stać się zachętą i pomocą do opracowania nowych katechizmów lokalnych, przystosowanych do różnorakich środowisk i kultur, a jednocześnie dbających o zachowanie jedności wiary oraz o wierność nauce katolickiej"60.

Katechizmy lokalne (narodowe i regionalne) może opracowywać Konferencja Episkopatu. Według postanowienia kan. $775 \S 2$,jeśli się to wyda pożyteczne, Konferencja Episkopatu zatroszczy się o wydanie katechizmów dla własnego terytorium, po uprzedniej aprobacie Stolicy Apostolskiej" ${ }^{61}$. Konferencja Biskupów nie ma obowiązku wydać katechizmu narodowego, ale może to uczynić, „jeśli się to wyda pożyteczne" ${ }^{2}$. Musi on jednak uzyskać wcześniejszą aprobatę Stolicy Apostolskiej, konkretnie Kongregacji ds. Duchowieństwa ${ }^{63}$.

„Uprzednie zatwierdzenie Stolicy Apostolskiej”, jakiego wymaga się dla katechizmów wydawanych przez Konferencje Episkopatu, powinno być rozumiane w ten sposób, że są one dokumentami, przez które Kościół powszechny, w różnych środowiskach społeczno-kulturowych, do których jest posłany, głosi i przekazuje Ewangelię oraz „rodzi Kościoły partykularne... wyrażając się w nich”64.

${ }^{56}$ Por. tamże 284, przypis 41.

57 Tamże 284.

58 Tamże 121.

59 Tamże 124.

60 Tamże 121

${ }^{61}$ Chodzi o katechizmy oficjalne, czyli takie, które Konferencja Episkopatu uznaje za swoje. DOK 131, przypis 31. Niektóre Konferencje Episkopatu, za aprobatą Stolicy Apostolskiej, opublikowały katechizmy narodowe: trzy katechizmy wydała Konferencja Biskupów Hiszpanii (Padre nuestro, Jesús es el Señor i Ésta es nuestra fe). Także Konferencja Biskupia Włoch określiła różne teksty do wykorzystania w katechizacji wiernych w różnym wieku: dla dzieci, chłopców, młodzieży, dorosłych i dorastających. J. Fuentes, Comentario..., s. 142.

${ }^{62}$ Na przykład w celu ujednolicenia metod nauczania na określonym terytorium czy poprawienia stanu edukacji religijnej. Por. J. Passicos, Le statut..., s. 151; por. J. Fuentes, Comentario..., s. 142.

${ }^{63}$ Constitutio Apostolica Pastor Bonus, art. 94; por. DCG 134; por. J. Passicos, Le statut..., s. 151; por. J. Fuentes, Comentario..., s. 141.

${ }^{64}$ DOK 285. 
W sprawie opracowania katechizmu nie można zapomnieć o instytucji synodu partykularnego (plenarnego lub prowincjalnego). Według kan. 445 synod partykularny zgodnie z prawem, któremu podlega, ma bez wątpienia kompetencje w materii katechetycznej dla Kościołów partykularnych jego terytorium ${ }^{65}$. W przypadku, gdyby wspomniany synod zdecydował się wydać katechizm, może to swobodnie uczynić i to na podstawie jedynie przejrzenia (recognitio), a nie aprobaty (aprobato) Stolicy Apostolskiej ${ }^{66}$. Wynika z tego, że jeśli chodzi o katechizm, to synod partykularny ma więcej swobody niż Konferencja Episkopatu ${ }^{67}$.

Odnośnie do aprobaty katechizmów wydanych przez Konferencję Episkopatu oprócz kan. 775 § 2 trzeba uwzględnić odpowiedzi Świętej Kongregacji Nauki Wiary z 7 lipca 1983 r. ${ }^{68}$ Na pytanie: ,czy narodowe i regionalne Konferencje Episkopatu mogą publikować katechizmy narodowe i regionalne oraz dokumenty katechetyczne, prawomocne na poziomie pozadiecezjalnym, bez uprzedniej aprobaty Stolicy Świętej”, dano odpowiedź negatywną ${ }^{69}$. Negatywną odpowiedź na kolejne pytanie: „czy bez uprzedniej aprobaty Stolicy Świętej mogą być proponowane i rozpowszechniane przez Konferencje Episkopatu w ramach jakiegoś narodu katechizmy w celu «konsultacji i eksperymentu» uzasadniono, że

jeśli chodzi o eksperymentowanie: nie można pozwolić na publikowanie katechizmów „ad experimentum”; katechizmy przeznaczone dla całego narodu muszą mieć tak co do treści, jak i co do metody uznaną wartość, która zapewnia autorytet i stałość, nadającą się do katechezy ${ }^{70}$.

Wreszcie na pytanie: „czy Komisja Episkopatu może mieć stały autorytet do aprobowania lub nie aprobowania katechizmów przeznaczonych dla całego na-

\footnotetext{
${ }^{65}$ „Synod partykularny powinien, w odniesieniu do własnego terytorium, zatroszczyć się o zaspokojenie potrzeb pasterskich Ludu Bożego. Wyposażony jest we władzę rządzenia, zwłaszcza ustawodawczą, tak aby — zachowując zawsze prawo powszechne Kościoła — mógł podejmować decyzje w tym, co wydaje się odpowiednie dla wzrostu wiary, ukierunkowania wspólnej działalności pasterskiej, poprawy obyczajów, zachowania, wprowadzenia lub strzeżenia jednakowej dyscypliny kościelnej”. Kan. 445.

66 „Po zakończeniu synodu partykularnego, przewodniczący winien zatroszczyć się o przesłanie wszystkich akt synodu do Stolicy Apostolskiej. Uchwały wydane przez synod nie mogą być promulgowane, dopóki nie zostaną przejrzane przez Stolicę Apostolską". Kan. 446.

${ }^{67}$ Por. J. Passicos, Le statut des instruments de cathéchèse, s. 151, 153.

${ }^{68}$ Sacra Congregatio pro Doctrina Fidei, Responsum ad propositum dubium (7 iulii 1984), „Acta Apostolicae Sedis” 75 (1984), s. 45-52. W dokumencie tym przypomina się, że ,jeśli chodzi o katechezę, zachowując prawo każdego Biskupa (por. KPK 1983, kan. 775, § 1; kan. 827, § 1), należy do kompetencji Konferencji Episkopatu, jeśli jest to użyteczne, publikowanie, za aprobatą Stolicy Apostolskiej, katechizmów dla własnego terytorium (por. KPK 1983, kan. 775, § 2; DCG, 119, 134)". Praefatio 3.

${ }^{69}$ Responsum..., Quaestio 1. Kongregacja odsyła do DCG 119, 134 oraz do kan. $775 \S 2$.

${ }^{70}$ Responsum... (7 iulii 1984), Quaestio 2.
} 
rodu bądź dla poszczególnych diecezji” padła także odpowiedź negatywna, z następującym uzasadnieniem:

odpowiedzialność curare ut catechismi pro suo teritorio, praevia Sedis stolicae approbatione, edantur należy kolegialnie do Konferencji Episkopatu. Komisji Episkopatu może być powierzone, także na stałe, przygotowanie materiału katechetycznego, zawsze jednak z wyjątkiem prawa Konferencji Episkopatu w jej całości do decydowania, czy akceptować go czy nie, i jeśli chodzi o katechizmy narodowe, czy przedstawić czy nie do aprobaty Stolicy Świętej. Taka decyzja, która dotyczy institutio catechetica, ustalona odpowiednio przez nowy Kodeks Prawa Kanonicznego w Księdze II De munere docendi, wchodzi w zakres prawa ustawodawczego Konferencji Episkopatu i jako taka powinna być podjęta przez bezwzględną większość, według normy kan. 455 , 2 , i nie może być delegowana ${ }^{71}$.

Zgodnie z postanowieniem kan. $775 \S 1$, przy zachowaniu przepisów wydanych przez Stolicę Apostolską, zadaniem biskupa diecezjalnego jest również troska o przygotowanie urzędowego (oficjalnego) katechizmu w razie potrzeby ${ }^{72}$. W wypadku gdy biskup zdecyduje się wydać jakiś katechizm jako urzędowy w swojej diecezji, zgodnie z kan. $775 \S 1$, nie będzie potrzebował uprzedniej kontroli ze strony Stolicy Apostolskiej, w przeciwieństwie do katechizmów i tekstów używanych w katechezie o charakterze narodowym, które będąc ogłaszane przez Konferencje Episkopatu, potrzebują uprzedniej aprobaty Stolicy Apostolskiej ${ }^{73}$.

Na podstawie kan. $823 \S 1$ wszystkie dzieła drukowane dotyczące wiary i obyczajów muszą być przedmiotem czujności pasterzy. Wspomniana czujność wyraża się przez imprimatur oraz system cenzorów ${ }^{74}$. Kodeks wyróżnia trzy rodzaje szczególnych przypadków kontroli dzieł drukowanych: księgi Pisma Świętego ${ }^{75}$, księgi liturgiczne ${ }^{76}$ i książki katechetyczne ${ }^{77}$. Pierwsze z nich dotyczą Objawienia zawartego w Piśmie, drugie odnoszą się do oficjalnej modlitwy Kościoła (lex orandi, lex credendi), książki katechetyczne zaś służą przekazaniu wiary ${ }^{78}$. Kate-

71 Tamże, Quaestio 4.

${ }^{72}$ Por. kan. 386 § 1; por. Responsum..., Praefatio 2, Quaestio 5 1; por. J. Passicos, Le statut..., s. 151.

${ }^{73}$ Por. J. Fuentes, Comentario..., s. 143.

${ }^{74}$ Kan. 830.

${ }^{75}$ Kan. 825 .

${ }^{76}$ Kan. 826.

77 Kan. 827.

${ }^{78}$ Chodzi w tym kanonie o katechizmy nieoficjalne (nieurzędowe), czyli takie, których Konferencja Episkopatu czy biskup diecezjalny nie uznają za swoje. DOK 131, przypis 31, DCG 116. 
chizmy te oraz inne pisma przeznaczone do katechizacji lub ich przekłady wymagają aprobaty ordynariusza miejsca bądź Konferencji Episkopatu ${ }^{79}$.

Oprócz katechizmów w nauczaniu używa się także „innych pism służących do katechizacji" "80. Są to teksty dydaktyczne przekazywane bezpośrednio do rąk katechumenów i katechizowanych, czyli pomoce dla katechizowanej społeczności chrześcijańskiej. Mają one wielkie znaczenie ponieważ są pomocne przy obszerniejszym wyjaśnianiu dokumentów chrześcijańskiej tradycji oraz elementów sprzyjających działalności katechetycznej. Przy redakcji tekstów potrzebna jest współpraca wielu osób biegłych w sprawach katechetycznych. Trzeba też wysłuchać zdania innych fachowców ${ }^{81}$.

Szczególnym rodzajem tekstów dydaktycznych są podręczniki katechetyczne, o których adhortacja apostolska Catechesi tradendae stwierdza:

jednym z ważniejszych sposobów odnowy katechetycznej jest dziś nowe opracowanie podręczników katechetycznych i zwiększenie ich liczby w całym prawie Kościele. Szczęśliwie ukazały się już liczne tego typu dzieła, stanowiące prawdziwy skarbiec dla dobra nauczania katechetycznego ${ }^{82}$.

Wśród ,innych pism służących do katechizacji” wyróżnia się też przewodniki dla katechetów, a w przypadku katechezy dzieci — dla rodziców ${ }^{83}$. Odnośnie do tych przewodników Ogólna Instrukcja Katechetyczna stwierdza:

tego rodzaju podręczniki winny zawierać: wykład orędzia zbawienia (trzeba sięgać do źródeł i dobrze rozróżniać między tym, co należy do wiary i obowiązującej nauki a tym, co stanowi jedynie opinie teologów); wskazania psychologiczne i pedagogiczne; sugestie metodyczne ${ }^{84}$.

Przywołane dyrektorium postuluje, aby przygotować również książki lub skrypty do ćwiczeń osób katechizowanych lub opublikowane jako osobne broszury ${ }^{85}$.

Wydaje się, że „innym pismom służącym do katechizacji” trzeba nadać taki sam statut jak katechizmom, stąd muszą być one poddane pod osąd kompetentnej władzy, który konkretyzuje się w akcie aprobaty ${ }^{86}$.

\footnotetext{
79 Por. kan. 775 § 2. Odnośnie do ordynariusza miejsca zob. kan. 134 § 1-2.

${ }^{80}$ Kan. $827 \S 1$.

${ }^{81}$ Por. DCG 120; por. DOK 283.

${ }^{82}$ CT 49.

${ }^{83}$ DOK 283. „Trzeba zatroszczyć się o wydanie książek jako pomoc dla rodziców w katechizacji dzieci”. DCG 121.

${ }^{84}$ DCG 121.

85 Tamże.

${ }^{86}$ Por. J. Passicos, Le statut..., s. 154-155.
} 
Gdy idzie o kryterium formalne aprobaty, to prawo jest jasne: wszelkie katechizmy i dokumenty z nimi zrównane lub bliskie im, podlegają aprobacie przez kompetentną władzę (ordynariusz miejsca albo Stolica Apostolska) ${ }^{87}$. Chodzi o akt kwalifikowany, który jest różny od zezwolenia (autoryzacji, zgody) ${ }^{88}$.

Materialnie aprobata różni się od imprimatur. To ostatnie oznacza, że nic w tym dziele nie przeciwstawia się wierze i obyczajom, może więc być ono opublikowane (chociażby nie zawsze było to stosowne). Aprobata oznacza, że dzieło jako takie zostało uznane za pozytywne pod względem treści i dyscypliny. Aprobata jawi się więc jako nowy, ponowny akt poza imprimatur ${ }^{89}$. Stąd J. Passicos jest zdania, że byłoby dobrze, gdyby aprobata katechizmu jako taka była wyszczególniona w katechizmie oprócz informacji o udzieleniu imprimatur ${ }^{90}$.

\section{Pozostałe narzędzia katechetyczne}

Poza katechizmami i różnego rodzaju drukami katechetycznymi według kan. 779 nauczanie katechetyczne winno być prowadzone z zastosowaniem wszelkich pomocy dydaktycznych. Stąd także w katechizacji „,pasterze Kościoła, korzystając z prawa przysługującego Kościołowi, powinni posługiwać się środkami społecznego przekazu"91.

Wśród „wszelkich pomocy dydaktycznych”, które mają służyć nauczaniu katechetycznemu, istotne miejsce zajmują środki audiowizualne, które są jedną z najbardziej rozwijających się dziedzin dydaktyki szkolnej, przynoszą bowiem wiele pozytywnych efektów w procesie edukacji. Rolę tych środków uwypukla adhortacja apostolska Catechesi tradendae, gdzie czytamy:

nasuwają się tu spontanicznie wielkie możliwości, jakich dostarczają zarówno środki społecznej informacji, jak również pomoce służące do przekazu grupowego: telewizja, prasa, radio, płyty, taśmy magnetofonowe oraz wszystkie urządzenia audiowizualne. Wysiłki dokonane już szczęśliwie w tej dziedzinie uprawniają do najlepszej nadziei. Doświadczenie wskazuje np. na wielkie efekty nauczania radiowego czy telewizyjnego, byleby łączyły się ze sobą wielka troska o wartości estetyczne i ścisła wierność dla Magisterium. Kościół ma obecnie wiele okazji do zajmowania się tym zagadnieniem — zwłaszcza w czasie dni poświęconych

87 Por. kan. $827 \S 1$.

88 Por. kan. $824 \S 1$.

${ }^{89}$ Por. J. Passicos, Le statut..., s. 155-156.

90 Tamże, s. 156.

${ }^{91}$ Kan. $822 \S 1$. 
środkom społecznej informacji - tak, że nie ma potrzeby dłużej się tutaj nim zajmować, chociaż ma ono wielkie znaczenie ${ }^{92}$.

Ogólna Instrukcja Katechetyczna zalicza pomoce audiowizualne do „głównych pomocy katechetycznych"93. Autorzy tego dokumentu rolę pomocy audiowizualnych widzą jako „dokumentację dla wzbogacenia katechezy elementami obiektywnymi. W tym wypadku mają się wyróżniać autentycznością, pilną selekcją wiadomości i przejrzystością dydaktyczną” oraz ,jako obrazy dla właściwego kształcenia uczuć i wyobraźni. Winny się przeto odznaczać pięknem i skutecznością w uszlachetnianiu ducha" ${ }^{94}$.

W związku z wykorzystaniem w katechizacji pomocy audiowizualnych pojawiają się następujące zadania: popieranie studium na temat kryteriów, które trzeba mieć na uwadze przy produkcji i selekcji tych środków, uwzględniając szczególne aspekty orędzia chrześcijańskiego, jakie mają być przedstawione, zespoły osób, dla których są przeznaczone, oraz wychowywanie katechetów do słusznej oceny tych środków (często bowiem zdarza się, że katecheci nie znają właściwego charakteru mowy za pomocą obrazów; znacznie częściej zdarza się również, że środki audiowizualne źle zastosowane nie wyrabiają czynnej postawy, lecz bierną itd. $)^{95}$.

Szczególnym rodzajem środków audiowizualnych są środki masowego przekazu, będące

pierwszym „areopagiem” współczesnym, który jednoczy ludzkość [...] Środki społecznego przekazu osiągnęły takie znaczenie, że dla wielu są głównym narzędziem informacyjnym i formacyjnym, przewodnikiem i natchnieniem w zachowaniach indywidualnych, rodzinnych, społecznych. Dlatego, oprócz zastosowania licznych środków tradycyjnych, wykorzystanie środków społecznego przekazu nabrało istotnego znaczenia dla ewangelizacji i katechezy ${ }^{96}$.

${ }^{92}$ CT 46.

${ }^{93}$ DCG 116. W Dyrektorium Ogólnym o Katechizacji znajduje się w tej kwestii następujący tekst: „tak samo ważne są środki audiowizualne, które wykorzystuje się w katechezie i wobec których trzeba dokonać odpowiedniego wyboru”. Nr 283.

${ }^{94}$ DCG 122.

${ }^{5}$ Tamże. Według Dyrektorium Ogólnego o Katechizacji „,kryterium inspirującym tych narzędzi roboczych powinna być podwójna wierność Bogu i osobie ludzkiej, która jest podstawowym prawem całego życia Kościoła. Chodzi tu o umiejętność połączenia doskonałej wierności doktrynalnej z głębokim przystosowaniem do człowieka, przy uwzględnieniu psychologii wieku i kontekstu społeczno-kulturowego, w jakim on żyje". Nr 283.

${ }^{96}$ DOK 160. 
Prawodawca kodeksowy wyraźnie nakazuje obowiązek wykorzystania w nauczaniu katechetycznym środków społecznego przekazu, by wierni, w sposób dostosowany do ich charakteru, możliwości, wieku oraz warunków życia, mogli głębiej poznać naukę katolicką i lepiej według niej układać życie ${ }^{97}$.

Środkami społecznego przekazu mogą być:

chociaż z różnych racji: telewizja, radio, prasa, płyty, taśmy magnetofonowe, wideo i audiokasety, dyski kompaktowe, cały sektor urządzeń audiowizualnych. Każdy z tych środków odgrywa swoją rolę i wymaga specyficznego zastosowania; każdy powinien być uznany i dowartościowany. W dobrze zaprogramowanej katechezie takie pomoce powinny więc zostać uwzględnione. Rozwijanie wzajemnej pomocy między Kościołami, by ograniczyć koszty zakupu i zastosowania, niekiedy dość wysokie, jest prawdziwą służbą na rzecz Ewangeliii ${ }^{8}$.

Właściwe używanie w katechezie środków społecznego przekazu stawia przed wykorzystującymi mass media określone zadania:

wymaga od pracujących w katechizacji poważnej troski o poznanie, kompetencję oraz umiejętne i aktualne wykorzystanie. Przede wszystkim jednak, ze względu na silny wpływ na kulturę, do której kształtowania przyczyniają się środki społecznego przekazu, nie należy zapominać, że nie wystarcza używać ich do szerzenia orędzia chrześcijańskiego i Magisterium Kościoła, ale trzeba włączyć samo orędzie $\mathrm{w}$ tę nową kulturę, stworzoną przez nowoczesne środki przekazu [...] z nowymi językami, nowymi technikami, nowymi postawami psychologicznymi. Tylko w ten sposób, z łaską Bożą, orędzie ewangeliczne jest zdolne przeniknąć do świadomości każdego oraz wzbudzić najbardziej osobiste przylgnięcie do niego i zaangażowanie ${ }^{99}$.

Niezwykle istotnym zadaniem katechetów (katechizacji) jest wychowanie pracowników środków społecznego przekazu i ich odbiorców do właściwego ko-

\footnotetext{
${ }^{97}$ Por. kan. 779; por. kan. 822.

${ }^{98}$ DOK 160. „Nasuwają się tu spontanicznie wielkie możliwości, jakich dostarczają zarówno środki społecznej informacji, jak również pomoce służące do przekazu grupowego: telewizja, prasa, radio, płyty, taśmy magnetofonowe oraz wszystkie urządzenia audiowizualne. Wysiłki dokonane już szczęśliwie w tej dziedzinie uprawniają do najlepszej nadziei. Doświadczenie wskazuje np. na wielkie efekty nauczania radiowego czy telewizyjnego, byleby łączyły się ze sobą wielka troska o wartości estetyczne i ścisła wierność dla Magisterium”. Kościół ma obecnie wiele okazji do zajmowania się tym zagadnieniem - zwłaszcza w czasie dni poświęconych środkom społecznej informacji — tak że nie ma potrzeby dłużej się tutaj nim zajmować, chociaż ma ono wielkie znaczenie. CT 46; por. J. Passicos, Le statut ..., s. 147; zob. H. Mussinghoff, H. Kahler, Verkündigungsamt ..., kan. $779 / 1$.

${ }^{99}$ DOK 161.
} 
rzystania z mass mediów, aby w posługiwaniu się środkami przekazu oraz $\mathrm{w}$ ich odbiorze odznaczali się zmysłem krytycznym, ożywianym umiłowaniem prawdy oraz podejmowali obronę wolności i poszanowania godności osoby, jak również popierali autentyczną kulturę poszczególnych narodów ${ }^{100}$.

\section{Zakończenie}

Prawodawca kościelny, widząc konieczność owocnej realizacji nauczania katechetycznego, domaga się, aby katechizacja była prowadzona z zastosowaniem wszelkich środków, pomocy dydaktycznych oraz środków społecznego przekazu. Obowiązek używania pomocy dydaktycznych jest mocno akcentowany zarówno w obowiązującym Kodeksie Prawa Kanonicznego, jak i w innych dokumentach kościelnych mających wymiar prawny.

Rozróżnia się dwa rodzaje środków katechizacji. Pierwsze to narzędzia poświęcone ukierunkowaniu i programowaniu całej działalności katechetycznej (analiza sytuacji, program działania i Dyrektorium katechetyczne), drugie to narzędzia robocze o zastosowaniu bezpośrednim, które są wykorzystywane w katechizacji (katechizmy i inne pisma służące katechizacji, które winny być zatwierdzone przez kompetentną władzę kościelną oraz środki audiowizualne i środki masowego przekazu).

\section{Aids of catechetical activity in terms of the canonic law}

\section{Summary}

This arcticle refers to the issue of means of catechesis in the canonical aspect. Firstly, there have been shown the rules which relate to necessity of using aids of catechetical activity. Then, it has been concentrated about issues of instruments dedicated to the orientation and general planning of catechetical activity in particular Church. Next it has been explained matter of catechisms and other writings pertaining to catechetical instruction. Finally, it has been focused on adio-visual aids and instruments of social communication in catechetical formation.

\section{Keywords}

catechesis, catechistic aids, catechism, didactic aids, directory for catechesis

\footnotetext{
${ }^{100}$ Por. tamże 162; por. kan. $822 \S 3$; por. J. Fuentes, Comentario..., s. 156.
} 


\section{Słowa kluczowe}

katecheza, pomoce katechetyczne, katechizm, pomoce dydaktyczne, dyrektorium katechetyczne

\section{Bibliografia}

\section{Źródła}

Codex Iuris Canonici. Schema novissimum iuxta placita Patrum Commissionis emendatum atque Summo Pontifici praesentatum, Typis Polyglottis Vaticanis 1982.

Ioannes Paulus P.P. II, Adhortatio Apostolica, Catechesi tradendae (16 octobris 1979), „Acta Apostolicae Sedis” 71 (1979), 1277-1340, tekst polski: Katecheza po Soborze Watykańskim II w świetle dokumentów Kościoła, red. W. Kubik, cz. II, Warszawa 1985, s. 146-217.

Ioannes Paulus P.P. II, Constitutio Apostolica Pastor Bonus (28 iulii 1988), „Acta Apostolicae Sedis" 80 (1988), s. 841-912.

Katechizm Kościoła Katolickiego, Poznań 1994.

Kongregacja ds. Biskupów, Dyrektorium o pasterskiej postudze biskupów „Apostolorum Successores", Kielce 2005.

Kongregacja ds. Duchowieństwa, Dyrektorium Ogólne o Katechizacji (15 sierpnia 1997), Poznań 1998.

Kongregacja ds. Duchowieństwa, Dyrektorium o posłudze i życiu kapłanów, Città del Vaticano 1994.

Kongregacja ds. Duchowieństwa, Ogólna Instrukcja Katechetyczna (11 kwietnia 1971), „Wiadomości Archidiecezjalne Warszawskie” 63 (1973), nr 2, s. 37-112.

Pontificia Commissio Codici Iuris Canonici Recognoscendo, Schema canonum libri III De ecclesiae munere docendi, Città del Vaticano 1977, tekst polski: „Posoborowe Prawodawstwo Kościelne", t. 11, z. 1, nr. 21077-21259, s. 286-328.

Sacra Congregatio pro Doctrina Fidei, Responsum ad propositum dubium (7 iulii 1984), „Acta Apostolicae Sedis” 75 (1984), s. 45-52.

Sacra Congregatio pro Episcopis, Directorium Ecclesiae imago de pastorali ministerio Episcoporum (22 februarii 1973), w: Enchiridion Vaticanum, v. 4, Bologna 1997, nr. 1945-2328, tekst polski: E. Sztafrowski, „Posoborowe Prawodawstwo Kościelne", t. 6, z. 1, nr. 10370-11035.

Schema Codicis Iuris Canonici, Libreria Editrice Vaticana 1980.

\section{Literatura}

Comentario exegético al Código de Derecho Canónico, red. A. Marzoa, J. Miras, R. Rodríguez-Ocaña, v. 3, p. I, Pamplona $2002^{3}$. 
Fuentes J., Comentario al can. 779, w: Comentario exegético al Código de Derecho Canónico, red. A. Marzoa, J. Miras, R. Rodríguez-Ocaña, v. 3, p. I, Pamplona 2002³, s. $155-156$.

Kommentar zum Codex Iuris Canonici, Bd. 3, hrsg. v. K. Lüdicke, Essen 1988-2001.

La funzione di insegnare della Chiesa, a cura di Gruppo Italiano Docenti di Diritto Canonico, Milano 1994.

Mussinghoff H., Kahler H., Verkündigungsamt: Dienst am Wort Gottes, w: Kommentar zum Codex Iuris Canonici, Bd. 3, hrsg. v. K. Lüdicke, Essen 1988-2001, kan 779.

Passicos J., Le statut des instruments de cathéchèse dans le Code, „L'Année canonique” 31 (1988), s. 147-156.

Szpet J., Dydaktyka katechezy, Poznań 1999.

Urru A., La funzione di insegnare della Chiesa, Roma 1988.

Urso P., Il ministero della parola divina: predicazione e catechesi (cann. 756-780), w: La funzione di insegnare della Chiesa, a cura di Gruppo Italiano Docenti di Diritto Canonico, Milano 1994, s. 25-49. 